\title{
Pengaruh Metakognisi dan Motivasi terhadap Kemampuan Pemecahan Masalah Matematika Melalui Kreativitas Siswa Kelas VIII SMP Negeri di Kecamatan Kindang Kabupaten Bulukumba
}

\author{
Muhammad Ihsan \\ Institut Agama Islam Negeri (IAIN) Palopo \\ Jl. Agatis, Balandai, Kota Palopo, Sulawesi Selatan, Indonesia \\ E-mail:ihsan@iainpalopo.ac.id
}

\begin{abstract}
Several factors that influence students' ability to solve mathematics problem are metacognition, learning motivation, and learning creativity on mathematics. Therefore, this research aimed to identify the influence level of metacognition and learning motivation toward mathematics problem solving ability through learning creativity of students. The population was students at grade VIII of public junior high school in Kindang sub district of Bulukumba. Technique of sampling was by equal size random sampling. The data were collected through questionnaire and test, and then analyzed by using descriptive statistics and SEM (Structural Equation Modeling) analysis. The result revealed that (1) there is a positive significant influence of metacognition toward learning creativity; (2) there is also a positive significant influence of learning motivation toward learning creativity; (3) the direct influence of metacognition toward mathematics problem solving ability is positive and significant; (4) the direct influence of learning motivation toward mathematics problem solving ability is positive significant; (5) there is a positive significant influence of learning creativity toward mathematics problem solving ability; (6) the indirect influence of metacognition toward mathematics problem solving ability through learning creativity is positive significant; and (7) the indirect influence of learning motivation toward mathematics problem solving ability through learning creativity is positive and significant.
\end{abstract}

Keywords: Problem Solving, Metacognition, Learning Motivation, and Creativity

\begin{abstract}
Abstrak
Beberapa faktor yang mempengaruhi kemampuan pemecahan masalah matematika siswa, diantaranya metakognisi, motivasi belajar siswa dan kreativitas belajar matematika siswa. Penelitian ini bertujuan untuk mengetahui seberapa besar pengaruh metakognisi dan motivasi belajar terhadap kemampuan pemecahan masalah matematika melalui kreativitas belajar siswa. Populasi penelitian adalah siswa kelas VIII SMP Negeri di Kabupaten Kindang Kabupaten Bulukkumba sebanyak 179 orang yang terdiri dari 8 kelas. Teknik penarikan sampel dilakukan secara equal size random sampling. Data diperoleh melalui kuesioner dan tes yang dianalisis dengan menggunakan statistika deskriptif dan analisis SEM (structural equation modeling). Hasil penelitian menunjukkan bahwa (1) Pengaruh metakognisi terhadap kreativitas belajar adalah positif dan signifikan; (2) Pengaruh motivasi belajar terhadap kreativitas belajar adalah positif dan signifikan; (3) Pengaruh metakognisi terhadap kemampuan pemecahan masalah matematika secara langsung adalah positif; (4) Pengaruh motivasi belajar terhadap kemampuan pemecahan masalah matematika secara langsung adalah positif dan signifikan; (5) Pengaruh kreativitas belajar terhadap kemampuan pemecahan masalah matematika adalah positif dan signifikan; (6) Pengaruh tidak langsung metakognisi dalam kemampuan pemecahan masalah matematika melalui kreativitas belajar adalah positif dan signifikan; (7) Pengaruh tidak langsung motivasi
\end{abstract}


belajar terhadap kemampuan pemecahan masalah matematika melalui kreativitas belajar adalah positif dan signifikan.

Kata Kunci: Pemecahan Masalah, Metakognisi, Motivasi Belajar, dan Kreativitas

\section{Pendahuluan}

Salah satu tujuan dari mata pelajaran matematika di tingkat sekolah menengah pertama (SMP) bertujuan agar peserta didik memiliki kemampuan pemecahan masalah yang meliputi kemampuan memahami masalah, merancang model matematika, menyelesaikan model dan menafsirkan solusi yang diperoleh. Tinggi rendahnya kemampuan pemecahan masalah matematika siswa diduga dipengaruhi oleh beberapa faktor diantaranya adalah metakognisi, motivasi belajar, dan kreativitas belajar siswa.

Pemecahan masalah adalah suatu pemikiran yang terarah secara langsung untuk menemukan suatu solusi/ jalan keluar untuk suatu masalah yang spesifik. Kita menemukan banyak masalah dalam kehidupan sehari-hari kita, sehingga kita akan membuat suatu cara untuk menanggapi, memilih, menguji respon yang kita dapat untuk memecahkan suatu masalah ${ }^{1}$.

Dalam penelitian ini, yang dimaksud dengan kemampuan pemecahan masalah matematika adalah suatu aktifitas intelektual untuk mencari penyelesaian masalah matematika yang dihadapi dengan bekal pengetahuan yang dimiliki yang diukur dengan indicator pemecahan masalah matematika. pengukuran kemampuan pemecahan masalah matematika siswa mengacu pada tahap-tahap pemecahan masalah menurut Polya, dengan penjabaran indikator sebagai berikut: (1) Mengidentifikasi masalah meliputi mengidentifikasi informasi yang diketahui dari soal dan mengidentifikasi apa yang ditanyakan dari soal; (2) Merencanakan penyelesaian masalah meliputi menentukan cara penyelesaian yang sesuai dan menggunakan informasi yang diketahui untuk mengembangkan informasi baru; (3) Menyelesaikan masalah meliputi mensubstitusi nilai yang diketahui dalam cara penyelesaian yang digunakan dan menghitung penyelesaian masalah; dan (4) Menginterpretasikan hasil yang diperoleh.

Metakognisi adalah salah satu aspek yang membangun kemampuan pemecahan masalah matematika siswa, hasil penelitian Yunus dan kawankawan mengungkapkan bahwa salah satu faktor yang dapat mempengaruhi kemampuan seseorang dalam memecahkan masalah matematika adalah metakognisi ${ }^{2}$. Lebih lanjut dikatakan bahwa metakognisi adalah thinking

\footnotetext{
${ }^{1}$ Robert L Solso, Psikologi Kognitif(Jakarta: Erlangga, 2008).

2 Aida Suraya Md.Yunus and Wan Zah Wan Ali, "Metacognition and Motivation in Mathematical Problem Solving," The International Journal of Learning: Annual Review 15, no. 3 (2008): 121-32, doi:10.18848/1447-9494/CGP/v15i03/45692.
} 
about thinking (berpikir tentang berpikir) atau learn how to learn (belajar bagaimana belajar) ${ }^{3}$. Metakognisi merupakan proses seseorang dalam belajar dan berpikir tentang pikiran mereka sendiri dalam rangka membangun strategi kognitif dan menyadari penggunaannya dalam proses belajar.

Berpikir tentang apa yang dipikirkan dalam hal ini berkaitan dengan kesadaran siswa terhadap kemampuannya untuk mengembangkan berbagai cara yang mungkin ditempuh dalam memecahkan masalah. Metakognisi terdiri dari dua komponen sebagaimana yang terdapat pada OLRC News yaitu: pengetahuan metakognitif dan regulasi metakognitif. Pengetahuan metakognitif mencakup (1) declarative knowledge, (2) procedural knowledge, (3) conditional knowledge. Sedangkan regulasi metakogniitf meliputi (1) Planning, (2) Information management strategies, (3) Comprehension monitoring, (4) Debugging strategies, dan (5) Evaluation. ${ }^{4}$

Dalam pemecahan masalah matematika motivasi belajar merupakan unsur penting yang harus dimiliki oleh siswa, siswa yang mempunyai motivasi belajar yang tinggi akan tekun dalam mengerjakan tugas, ulet dan pantang menyerah dalam memecahkan berbagai masalah dan hambatan, menaruh minat terhadap proses pembelajaran, memikirkan pemecahan masalah khususnya yang berkaitan dengan masalah Matematika.

Hakikat motivasi belajar adalah dorongan internal dan eksternal pada peserta didik-peserta didik yang sedang belajar untuk mengadakan perubahan tingkah laku, pada umumnya dengan beberapa indikator atau unsur pendukung. Indikator motivasi belajar dapat diklasifikasikan sebagai berikut: (a) hasrat dan keinginan berhasil; b) dorongan dan kebutuhan dalam belajar; (c) harapan dan cita-cita masa depan; d) penghargaan dalam belajar; (e) kegiatan yang menarik dalam belajar; dan (f) lingkungan belajar yang kondusif, sehingga memungkinkan peserta didik dapat belajar dengan baik ${ }^{5}$.

Pada proses pemecahan masalah matematika sangat bergantung pada cara berpikir seseorang, cepat atau lambatnya seorang siswa dalam menyelesaikan masalah matematika ditentukan oleh pengetahuan dan cara pandangya terhadap masalah tersebut, cara pandang seorang siswa tidak selalu sama dengan siswa yang lain.

3 Nurdin, "Model Pembelajaran Matematika Yang Menumbutuhkan Kemampuan Metakognitif Untuk Menguasai Bahan Ajar" (UNESA, 2007).

4 OLRC News, "Metakognition," 2007, www.literacy.kent.edu.ohioeffesource.doc.

${ }^{5}$ Hamzah B Uno, Teori Motivasi Dan Pengukurannya: Analisis Di Bidang Pendidikan (Jakarta: Bumi Aksara, 2012). 
Kreativitas adalah kemampuan untuk membuat kombinasi-kombinasi baru, atau melihat hubunganhubungan baru antar unsur, data, atau hal-hal yang sudah ada sebelumnya ${ }^{6}$. Kreativitas dibentuk dari dari berbagai dorongan seperti dari dalam diri individu (motivasi intrinsik) maupun dorongan dari luar atau lingkungan (motivasi ekstrinsik). Dorongan demi mewujudkan potensi diri seseorang untuk berkembang dan menjadi matang, dorongan untuk mengungkapkan dan mengaktifkan semua kapisitas seseorang merupakan motivasi primer untuk kreativitas ketika individu membentuk hubungan-hubungan baru dengan lingkungannya.

Adapun indikator kreativitas belajar matematika yang digunakan adalah: (1) Keterampilan berpikir lancar (fluency), (2) Keterampilan berpikir luwes (flexibility), (3) Keterampilan berpikir orisinal (originality), dan (4) Keterampilan memperinci (elaboration) ${ }^{7}$.

\section{Hipotesis Penelitian}

Hipotesis menyangkut prediksi langsung

Hipotesis Ke-1 Metakognisi berpengaruh positif terhadap kreativitas

Hipotesis ke-2 Motivasi belajar berpengaruh positif terhadap kreativitas.

Hipotesis ke-3 Metakognisi berpengaruh positif terhadap kemampuan pemecahan masalah Matematika siswa

Hipotesis Ke-4 Motivasi Belajar berpengaruh positif terhadap kemampuan pemecahan masalah Matematika siswa.

Hipotesis Ke-5 Kreativitas berpengaruh positif terhadap kemampuan pemecahan masalah Matematika siswa.

Hipotesis menyangkut prediksi tidak langsung.

Hipotesis Ke-6 Metakognisi memiliki pengaruh tidak langsung yang positif dan sifnifikan terhadap kemampuan pemecahan masalah matematika melalui kreativitas

Hipotesis Ke-7 Motivasi belajar memiliki pengaruh tidak langsung yang positif dan signifikan terhadap kemampuan pemecahan masalah matematika melalui kreativitas

\footnotetext{
${ }^{6}$ Purwoko Yudi Riawan, “Eksperimentasi Pembelajaran Matematika Realistik Dengan Metode Penemuan Ditinjau Dari Kreativitas Belajar Matematika Siswa," LIMIT - Pendidikan Matematika $0, \quad 11$ no. April 24, http://ejournal.umpwr.ac.id/index.php/limit/article/view/24. 2009).

7 Utami Munandar, Pengembangan Kreativitas Anak Berbakat (Jakarta: Rineka Cipta,
} 


\section{Metode Penelitian}

Populasi penelitian ini adalah siswa kelas VIII SMP Negeri di Kecamtan Kindang Kabupaten Bulukumuba semester II 2012 / 2013, yang terdiri dari 8 kelas. Metode pengambilan sampel yang digunakan untuk memperoleh sampel acak dan dapat merepresentasikan karakteristik populasi adalah menggunakan teknik equal size random sampling. Dengan mengambil 2 kelas pada SMPN 36, 2 kelas pada SMPN 37, dan 2 kelas pada SMPN 38 Bulukumba.

Pengukuran terhadap empat variabel penelitian dilakukan dengan tes kemampuan pemecahan masalah metamatika, skala metakognisi, dan skala motivasi belajar, skala kreativitas belajar. Untuk tes kemampuan pemecahan masalah matematika terdiri dari 3 soal. Untuk instrument dengan metode skala disertai dengan 4 pilihan jawaban, yaitu: sangat sesuai dengan kenyataan pada diri saya, sesuai dengan kenyataan pada diri saya, tidak sesuai dengan kenyataan pada diri saya, dan sangat tidak sesuai dengan kenyataan pada diri saya.

Untuk mendukung dalam penunjukan hipotesis penelitian yang dikemukakan, data yang telah dikumpulkan dengan angket yang telah dibuat, maka selanjutnya untuk melihat sejauh mana signifikan hipotesis yang dibuat dapat terbukti dengan kegiatan penelitian yang dilakukan, data yang dikumpulkan diolah dengan teknik statistika deskriptif dan inferensial. Teknik analisis yang digunakan adalah statistik deskriptif, diperlukan untuk mendeskripsikan data dari variabel-variabel penelitian yang diajukan. Untuk teknik analisis deskriptif meliputi mean, median, variansi, skewness, kurtosis, minimum, maksimum, dan tabel distribusi frekuensi. Statistika inferensial dimaksudkan untuk analisis dan validasi model yang diusulkan serta pengujian hipotesis. Statistika inferensial yang digunakan adalah teknik analisis SEM dengan menggunakan paket program IBM SPSS Statistics 20 dan IBM SPSS AMOS (Analysis Of Moment Structure) 20.

Berdasarkan hasil penelitian yang diperoleh bahwa secara umum ratarata skor yang diperoleh siswa SMP Negeri di Kecamatan Kindang Kabupaten Bulukumba adalah sebesar untuk variabel metakognisi adalah sebesar 57,34 yang berada dalam kategori baik, skor rata-rata motivasi belajar sebesar 34,087 yang tergolong tinggi, Adapun skor rata-rata untuk variabel kreativitas sebesar 42,339 yang berada dalam kategori kreatif. Sedangkan, skor rata-rata untuk variable kemampuan pemecahan masalah matematika diperoleh sebesar 11,331 yang berada pada kategori tinggi.

Berdasarkan hasil analisis statitika inferensial dengan menggunakan program AMOS diperoleh hasil sebagai berikut: 
Tabel. 1 Estimasi parameter (regression weight) Model Tahap Akhir

\begin{tabular}{|l|c|l|l|c|c|c|}
\hline Regression weight & & & Estimate & S.E. & C.R. & P \\
\hline Kreativitas (Y1) & $<---$ & $\begin{array}{l}\text { Metakognisi } \\
\text { (X1) }\end{array}$ & 0.917 & $\begin{array}{c}0.21 \\
3\end{array}$ & 4.309 & 0.000 \\
\hline Kreativitas (Y1) & $<---$ & Motivasi (X2) & 0.229 & $\begin{array}{c}0.08 \\
4\end{array}$ & 2.713 & 0.007 \\
\hline $\begin{array}{l}\text { Pemecahan_Masalah } \\
(Y 2)\end{array}$ & $<---$ & Motivasi (X2) & 0.089 & $\begin{array}{c}0.04 \\
2\end{array}$ & 2.093 & 0.036 \\
\hline $\begin{array}{l}\text { Pemecahan_Masalah } \\
\text { (Y2) }\end{array}$ & $<---$ & $\begin{array}{l}\text { Metakognisi } \\
(\mathrm{X} 1)\end{array}$ & 0.389 & $\begin{array}{c}0.12 \\
2\end{array}$ & 3.200 & 0.001 \\
\hline $\begin{array}{l}\text { Pemecahan_Masalah } \\
\text { (Y2) }\end{array}$ & $<---$ & $\begin{array}{l}\text { Kreativitas } \\
(Y 1)\end{array}$ & 0.225 & $\begin{array}{c}0.09 \\
2\end{array}$ & 2.462 & 0.014 \\
\hline
\end{tabular}

Tabel 2 Pengaruh langsung

\begin{tabular}{|l|r|r|r|}
\hline \multirow{2}{*}{ Variabel Endogen } & \multicolumn{3}{|c|}{ Variabel Eksogen } \\
\cline { 2 - 4 } & Metakognisi & Motivasi & Kreativitas \\
\hline Kreativitas (Y1) & 0.784 & 0.269 & 0.000 \\
\hline Pemecahan_Masalah (Y2) & 0.565 & 0.177 & 0.382 \\
\hline
\end{tabular}

Tabel 3 Pengaruh tak langsung

\begin{tabular}{|l|r|r|}
\hline \multirow{2}{*}{ Variabel Endogen } & \multicolumn{2}{|c|}{ Variabel Eksogen } \\
\cline { 2 - 3 } & Metakognisi & Motivasi \\
\hline Kreativitas (Y1) & 0.000 & 0.000 \\
\hline Pemecahan_Masalah (Y2) & 0.300 & 0.103 \\
\hline
\end{tabular}

Tabel 4 Pengaruh total

\begin{tabular}{|l|r|r|r|}
\hline \multirow{2}{*}{ Variabel Endogen } & \multicolumn{3}{c|}{ Variabel Eksogen } \\
\cline { 2 - 4 } & Metakognisi & Motivasi & Kreativitas \\
\hline Kreativitas(Y1) & 0.784 & 0.269 & 0.000 \\
\hline Pemecahan_Masalah (Y2) & 0.565 & 0.380 & 0.382 \\
\hline
\end{tabular}

Persamaan struktural yang sesuai berdasarkan model Tahap Final dan korelasi multipel kuadratnya sebagaimana dalam tabel 2 adalah

$$
\begin{array}{lr}
Y_{1}=0,784 X_{1}+0,269 X_{2}+0,560 & R_{y 1}^{2}=68,6 \% \\
Y_{2}=0,565 X_{1}+0,177 X_{2}+0,382 Y_{1}+0,359 & R_{y 2}^{2}=87,1 \%
\end{array}
$$

Keterangan

$X_{1}$ dan $X_{2}$ berturut-turut adalah metakognisi dan Motivasi belajar

$Y_{1}$ dan $Y_{2}$ berturut-turut adalah kreativitas dan kemampuan pemecahan masalah matematika 
Berdasarkan hasil uji hipotesis pertama yang dilakukan maka diperoleh hasil penelitian terdapat pengaruh positif dan signifkan antara metakognisi dan kreativitas, Hasil penelitian ini sejalan dengan hasil penelitian yang dilakukan Kuntjojo dimana metakognisi berkorelasi positif secara kuat dengan kreativitas ${ }^{8}$. Diterimanya hasil ini juga berarti temuan ini mendukung dengan yang diungkapkan oleh Puccio dan Mudock bahwa dalam berpikir kreatif memuat aspek ketrampilan kognitif dan metakognitif antara lain mengidentifikasi masalah, menyusun pertanyaan, mengidentifikasi data yang relevan dan tidak relevan, produktif, mengahasilkan banyak ide-ide yang berbeda dan produk atau ide yang baru dan memuat disposisi yaitu bersikap terbuka, berani mengambil posisi, bertindak cepat, bersikap atau berpandangan bahwa sesuatu adalah bagian dari keseluruhan yang kompleks, memanfaatkan cara berpikir orang lain yang kritis, dan sikap sensitif terhadap perasaan orang lain 9.

Berdasarkan hasil uji hipotesis kedua yang dilakukan maka diperoleh hasil penelitian terdapat pengaruh positif dan signifkan antara motivasi dan kreativitas. Hasil ini sejalan dengan penelitian yang dilakukan oleh Hayati yang menyatakan bahwa terdapat hubungan yang positif antara motivasi belajar matematika dengan kemampuan berpikir kreatif matematik ${ }^{10}$. Hasil penelitian yang lain yang dilakukan oleh Kuntjojo mengungkapkan bahwa ada hubungan positif yang sangat signifikan antara motivasi berprestasi dengan kreativitas ${ }^{11}$.

Berdasarkan uji hipotesis ketiga yang dilakukan maka diperoleh hasil penelitian terdapat pengaruh positif dan signifkan antara metakognisi dan kemampuan pemecahan masalah matematika, Hasil penelitian ini sesuai dengan penelitian yang dilakukan Ilhamsyah dimana terdapat pengaruh yang sigfikan anata metakognisi denga prestasi belajar matematika dengan sumbangan efektif metakognisi secara langsung terhadap prestasi belajar matematika yaitu $60,2 \% 12$

8 Kuntjojo and Andik Matulessy, "Hubungan Antara Metakognisi Dan Motivasi Berprestasi Dengan Kreativitas," Jurnal Psikologi Persona 1, no. 1 (June 2012), http://drmasda.com/berita-148-hubungan-antara-metakognisi-dan-motivasi-berprestasidengan-kreativitas.html.

${ }^{9}$ Lamoma, "Kemampuan Berpikir Kreatif Matematika," in Seminar Nasional UNPATI (UNPATI: UNPATI, 2011).

${ }^{10}$ Hayati, "Hubungan Antara Motivasi Dan Kemandirian Belajar Dengan Kemampuan Berpikir Kreatif Matematik Peserta Didik Yang Pembelajarannya Menggunakan Pembelajaran Berbasis Masalah," Universitas Siliwangi Tasikmalaya, 2010.

11 Kuntjojo and Matulessy, "Hubungan Antara Metakognisi Dan Motivasi Berprestasi Dengan Kreativitas."

12 Ilhamsyah, "Pengaruh Efikasi Diri, Metakognisi Dan Regulasi Diri Terhadap Prestasi Belajar Matematika Siswa Kelas X Sms Negeri Di Kabupaten Wajo” (UNM Makassar, 2012). 
Metakognisi sangat penting pada pembelajaran matematika yang akan membantu siswa untuk belajar bagaimana belajar matematika dengan baik. Siswa akan tahu bentuk umum cara menyelesaikan permasalahan matematik, dan itu akan dijadikannya stereotype bagaimana seharusnya menyelesaikan matematika dengan baik dan benar serta cepat ${ }^{13}$.

Berdasarkan hasil uji hipotesis keempat yang dilakukan maka diperoleh hasil penelitian terdapat pengaruh positif dan signifkan antara metakognisi dan kreativitas. Hasil penelitian ini sesuai dengan penelitian yang dilakukan oleh Wongkar yang mengungkapkan bahwa motivasi memiliki pengaruh dengan hasil belajar siswa, pengaruh tersebut juga berbanding lurus dan sangat berarti, menunjukan bahwa motivasi mempengaruhi hasil belajar siswa ${ }^{14}$.

Selanjutnya Muzaki dalam penelitiannya mengungkapkan terdapat pengaruh yang berarti signifikan antara motivasi belajar dengan kemampuan pemecahan masalah matematika ${ }^{15}$. Berdasarkan hasil uji hipotesis kelima yang dilakukan maka diperoleh hasil penelitian terdapat pengaruh positif dan signifkan antara metakognisi dan kreativitas. Hasil penelitian ini sesuai dengan penelitian yang dilakukan oleh Widjonarko yang menyatakan bahwa pengaruh kreativitas terhadap hasil belajar ${ }^{16}$, dimana variabel kreativitas $(X)$ memberikan pengaruh positif terhadap hasil belajar $(Y$ ) juga dengan $\mathrm{R}$ Square 0,165 artinya variable kreativitas $(X)$ memberikan kontribusi terhadap hasil belajar ( $Y$ ) sebesar 16,5\%. Muzaki dalam penelitiannya mengungkapkan terdapat pengaruh yang berarti signifikan antara motivasi belajar kreativitas belajar dengan kemampuan pemecahan masalah matematika17.

${ }^{13}$ Khamim Tohari, "Peningkatan Kemampuan Problem Solving Melalui Peningkatan Kemampuan Metakognisi," 2010, http://bdksurabaya.kemenag.go.id.

14 Wongkar, "Pengaruh Motivasi Dan Kreativitas Terhadap Hasil Belajar Siswa Program Studi Teknik Instalasi Tenaga Listrik Di Smk Negeri 2 Manado," Universitas Negeri Manado 1, no. 2 (May 28, 2013).

15 Fiqi Ibnu Muzaki, "Pengaruh Kreativitas Dan Motivasi Belajar Siswa Terhadap Kemampuan Siswa Memecahkan Masalah Matematika Di Dalam Model Pembelajaran Problem Solving Materi Ajar Perbandingan Di Smp Muhammadiyah I Kota Tegal Kelas Vii Tahun Ajaran 2009/2010" (other, Universitas Negeri Semarang, 2010), http://lib.unnes.ac.id/2953/.

16 Widjonarko, "Ipi Pengaruh Pembelajaran Matematika Dengan Strategi "pattern of Student Creatifity" Pada Materi Kesebangunan Siswa Kelas Ix: View Article," IKIP PGRI Semarang, 2011, http://id.portalgaruda.org/index.php?ref=browse\&mod=viewarticle\&article=6863.

17 Muzaki, "Pengaruh Kreativitas Dan Motivasi Belajar Siswa Terhadap Kemampuan Siswa Memecahkan Masalah Matematika Di Dalam Model Pembelajaran Problem Solving Materi Ajar Perbandingan Di Smp Muhammadiyah I Kota Tegal Kelas Vii Tahun Ajaran 2009/2010." 
Berdasarkan hasil uji hipotesis keenam yang dilakukan maka diperoleh hasil penelitian terdapat pengaruh positif dan signifkan antara metakognisi dan kemampuan pemecahan masalah matematika melalui kreativitas belajar, Hasil pengujian hipotesis sebelumnya yang diungkapkan bahwa pengaruh metakognisi terhadap kreativitas belajar ditunjukkan bahwa pengaruhnya positif dan signifikan. Yang mendukung penelitian yang dilakukan oleh Kuncjojo metakognisi berkorelasi positif secara kuat dengan kreativitas ${ }^{18}$. Demikian juga hipotesis yang ditunjukkan bahwa kreativitas berpengaruh positif dan signifikan terhadap kemampuan pemecahan masalah matematika. Dan mendukung hasil penelitian yang dilakukan oleh Muzaki dimana kreativitas belajar berpengaruh secara signifikan terhadap kemampuan pemecahan masalah matematika ${ }^{19}$. Sehingga dengan demikian metakognisi berpengaruh secara tidak langsung terhadap kemampuan pemecahan masalah matematika melalui kreativitas belajar atau kreativitas belajar memperkuat pengaruh metakognisi terhadap kemampuan pemecahan masalah matematika.

Berdasarkan hasil uji hipotesis ketujuh yang dilakukan maka diperoleh hasil penelitian terdapat pengaruh positif dan signifkan antara motivasi belajar dan kemampuan pemecahan masalah matematika melalui kreativitas belajar, Berdasarkan hasil uji hipotesis sebelumnya bahwa motivasi belajar berpengaruh positif dan signifikan terhadap kreativitas belajar. Hasil ini mendukung hasil penelitian yang dilakukan oleh Suharnan yang mengungkapkan bahwa motivasi intrinsik berperan penting di dalam prosesproses kreatif ${ }^{20}$. Hasil uji hipotesis lain yang menunjukkan bahwa ada pengaruh positif dan signifikan pengaruh kreativitas belajar terhadap kemampuan pemecahan masalah matematika. Hasil penelitian ini mendukung hasil penelitian yang diungkapakan oleh Mahmudi dimana kemampuan berpikir kreatif (Kretivitas) diperlukan untuk memecahankan masalah, tanpa kemampuan berpikir kreatif, individu sulit mengembangkan kemampuan imajinatifnya sehingga kurang mampu melihat berbagai alternatif solusi masalah, khususnya masalah kompleks ${ }^{21}$. Berdasarkan hal tersebut maka secra tidak langsung motivasi berpengaruh positif terhadap kemampuan pemecahan masalah matematika melalui kreativitas belajar atau

18 Kuntjojo and Matulessy, "Hubungan Antara Metakognisi Dan Motivasi Berprestasi Dengan Kreativitas."

${ }_{19}$ Muzaki, "Pengaruh Kreativitas Dan Motivasi Belajar Siswa Terhadap Kemampuan Siswa Memecahkan Masalah Matematika Di Dalam Model Pembelajaran Problem Solving Materi Ajar Perbandingan Di Smp Muhammadiyah I Kota Tegal Kelas Vii Tahun Ajaran 2009/2010."

${ }^{20}$ Kuntjojo and Matulessy, "Hubungan Antara Metakognisi Dan Motivasi Berprestasi Dengan Kreativitas."

21 Ali Mahmudi, "Pemecahan Masalah Dan Berpikir Kreatif" (Konferensi Nasional Matematika (KNM) XIV, Universitas Sriwijaya Palembang, 2008). 
kreativitas belajar meperkuat pengaruh motivasi belajar terhadap kemampuan pemecahan masalah matematika.

\section{Penutup}

Berdasarkan hasil penelitian dan pembahasan, maka kesimpulan dalam peneleitian ini adalah sebagai berikut: (1) Secara umum siswa kelas VIII SMP Negeri di Kecamatan Kindang Kabupaten Bulukumba memiliki metakognisi dalam belajar matematika dengan kategori baik, Motivasi dalam belajar matematika dengan kategori tinggi, Kreativitas dalam belajar matematika dengan kategori kreatif, dan kemampuan pemecahan masalah matematika berada pada kategori tinggi; (2) Metakognisi berpengaruh positif yaitu sebesar 61, 5\% dan signifikan terahadap kreativitas Belajar; (3) Motivasi belajar berpengaruh positif yaitu sebesar 7,2 \%. dan signifikan terhadap kreativitas belajar; (4) Metakognisi berpengaruh positif yaitu sebesar 48,8 $\%$ dan signifikan terhadap Kemampuan pemecahan masalah matematika secara langsung; (5) Motivasi belajar berpengaruh positif yaitu sebesar 4,9 $\%$ dan signifikan terhadap Kemamapuan pemecahan masalah matematika secara langsung; (6) Kreativitas belajar berpengaruh positif yaitu sebesar $14,59 \%$ dan signifikan terhadap Kemamapuan pemecahan masalah matematika; (7) Metakognisi berpengaruh positif yaitu sebesar 30\% dan signifikan terhadap kemampuan pemecahan masalah matematika melalui kreativitas belajar secara tidak langsung; (8) Motivasi belajar berpengaruh positif yaitu sebesar 10,3\%. dan signifikan terhadap kemampuan pemecahan masalah matematika melalui kreativitas belajar secara tidak langsung.

Berdasarkan kesimpulan di atas, maka peneliti menyarankan beberapa hal yang perlu diperhatikan: (1) Kepada para Guru matematika sebaiknya memperhatikan beberapa faktor yang dapat mempengaruhi hasil belajar siswa khususnya pemecahan masalah matematika siswa diantaranya metakognisi, motivasi belajar, kreativitas belajar dalam belajar dan mengajar matematika sehingga dapat berimplikasi pada peningkatan kemampuan pemecahan masalah matematika siswa; (2) Hedaknya para guru matematika mengembangkan pembelajaran yang melibatkan metakognisi siswa, secara aktif memberi siswa motivasi belajar dan memberi siswa ruang untuk berkreasi dalam pembelajaran matematika dan mengajarkan siswa cara cara untuk menyelesaikan masalah matematika khususnya soal yang non rutin sehingga siswa akan menjadi terampil dalam memecahkan masalah matematika yang berimplikasi pada peningkatan hasil belajar matematika. (3) Diharapkan dalam penelitian selanjutnya, penulis/peneliti memilih variabel-variabel lainnya sebagai faktor internal-eksternal siswa yang diduga 
berpengaruh terhadap Kemampuan pemecahan masalah matematika baik berpengaruh langsung maupun berpengaruh tidak langsung.

\section{Daftar Pustaka}

Hayati. "Hubungan Antara Motivasi Dan Kemandirian Belajar Dengan Kemampuan Berpikir Kreatif Matematik Peserta Didik Yang Pembelajarannya Menggunakan Pembelajaran Berbasis Masalah." Universitas Siliwangi Tasikmalaya, 2010.

Ilhamsyah. "Pengaruh Efikasi Diri, Metakognisi Dan Regulasi Diri Terhadap Prestasi Belajar Matematika Siswa Kelas X Sms Negeri Di Kabupaten Wajo." UNM Makassar, 2012.

Kuntjojo, and Andik Matulessy. "Hubungan Antara Metakognisi Dan Motivasi Berprestasi Dengan Kreativitas." Jurnal Psikologi Persona 1, no. 1 (June 2012). http://drmasda.com/berita-148-hubungan-antarametakognisi-dan-motivasi-berprestasi-dengan-kreativitas.html.

Lamoma. "Kemampuan Berpikir Kreatif Matematika." In Seminar Nasional UNPATI. UNPATI: UNPATI, 2011.

Mahmudi, Ali. "Pemecahan Masalah Dan Berpikir Kreatif." Universitas Sriwijaya Palembang, 2008.

Md.Yunus, Aida Suraya, and Wan Zah Wan Ali. "Metacognition and Motivation in Mathematical Problem Solving." The International Journal of Learning: Annual Review 15, no. 3 (2008): 121-32. doi:10.18848/1447-9494/CGP/v15i03/45692.

Munandar, Utami. Pengembangan Kreativitas Anak Berbakat. Jakarta: Rineka Cipta, 2009.

Muzaki, Fiqi Ibnu. "Pengaruh Kreativitas Dan Motivasi Belajar Siswa Terhadap Kemampuan Siswa Memecahkan Masalah Matematika Di Dalam Model Pembelajaran Problem Solving Materi Ajar Perbandingan Di Smp Muhammadiyah I Kota Tegal Kelas Vii Tahun Ajaran 2009/2010." Other, Universitas Negeri Semarang, 2010. http://lib.unnes.ac.id/2953/.

Nurdin. "Model Pembelajaran Matematika Yang Menumbutuhkan Kemampuan Metakognitif Untuk Menguasai Bahan Ajar.” UNESA, 2007.

OLRC News. "Metakognition," 2007. www.literacy.kent.edu.ohioeffesource.doc.

Riawan, Purwoko Yudi. "Eksperimentasi Pembelajaran Matematika Realistik Dengan Metode Penemuan Ditinjau Dari Kreativitas Belajar Matematika Siswa." LIMIT - Pendidikan Matematika 0, no. 11 (April 24, 2012).

http://ejournal.umpwr.ac.id/index.php/limit/article/view/24.

Solso, Robert L. Psikologi Kognitif. Jakarta: Erlangga, 2008.

Tohari, Khamim. "Peningkatan Kemampuan Problem Solving Melalui Peningkatan Kemampuan Metakognisi," 2010. http://bdksurabaya.kemenag.go.id.

Uno, Hamzah B. Teori Motivasi Dan Pengukurannya: Analisis Di Bidang Pendidikan. Jakarta: Bumi Aksara, 2012. 
Widjonarko. "Ipi Pengaruh Pembelajaran Matematika Dengan Strategi "pattern of Student Creatifity" Pada Materi Kesebangunan Siswa Kelas Ix: View Article." IKIP PGRI Semarang, 2011. http://id.portalgaruda.org/index.php?ref=browse\&mod=viewarticle \&article $=6863$.

Wongkar. "Pengaruh Motivasi Dan Kreativitas Terhadap Hasil Belajar Siswa Program Studi Teknik Instalasi Tenaga Listrik Di Smk Negeri 2 Manado." Universitas Negeri Manado 1, no. 2 (May 28, 2013). 